Discussion Paper No. 11-045

\title{
Intrinsic Work Motivation and Pension Reform Acceptance
}

Friedrich Heinemann, Tanja Hennighausen, and Marc-Daniel Moessinger

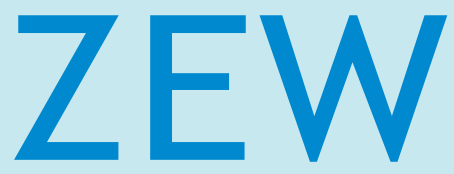

Zentrum für Europäische Wirtschaftsforschung $\mathrm{GmbH}$

Centre for European

Economic Research 
Discussion Paper No. 11-045

\title{
Intrinsic Work Motivation and Pension Reform Acceptance
}

\author{
Friedrich Heinemann, Tanja Hennighausen, \\ and Marc-Daniel Moessinger
}

Download this ZEW Discussion Paper from our ftp server:

http://ftp.zew.de/pub/zew-docs/dp/dp11045.pdf

Die Discussion Papers dienen einer möglichst schnellen Verbreitung von neueren Forschungsarbeiten des ZEW. Die Beiträge liegen in alleiniger Verantwortung der Autoren und stellen nicht notwendigerweise die Meinung des ZEW dar.

Discussion Papers are intended to make results of ZEW research promptly available to other economists in order to encourage discussion and suggestions for revisions. The authors are solely responsible for the contents which do not necessarily represent the opinion of the ZEW. 


\section{Non-technical Summary}

Reforms, such as a higher pension age, are highly unpopular although they are a demographic necessity. Hence, a sound understanding of reform resistance is desirable. Preceding studies have explored numerous important drivers of pension reform acceptance. According to these insights, an individual's socio-economic characteristics like gender, income or age matter as does the degree of information on the extent of the system imbalances. So far, however, the literature has not looked into another potential source of reform resistance which is related to an individual's (dis-)utility from work. Thus, this contribution argues that intrinsic motivation must not be overlooked in a comprehensive analysis of pension reform preferences. Pension reforms impose or reduce restrictions on ageing citizens to offer their work at the labor market. Therefore, an individual's work motivation should have an impact on reform preferences. People with intrinsic work motivation will be less anxious about longer working years compared to people for whom work is a burden.

To specify the theoretical link between work motivation and pension reform acceptance, we regard the formation of pension age preferences within the framework of an optimal job separation decision. In this framework, a higher pension age should be a relatively attractive reform option for intrinsically motivated workers compared to the reform alternatives of cutting pensions or increasing contributions.

In the empirical part, this prediction is tested for data from the representative ALLBUS survey (German General Social Survey) of the German population. The results strongly confirm that (lacking) intrinsic work motivation is a robust determinant for individual (resistance and) support for a higher pension age. This key result has numerous implications, both for the intrinsic motivation literature and our understanding of reform processes. So far, intrinsic motivation has been recognized to be important for the efficiency of firms and organizations. Our findings point beyond that insight towards the formation of policy preferences and the adaptability of modern welfare states and societies. A lack of non-monetary incentives will contribute to the blockade of reforms which require more work effort. Hence, a society for which work is perceived as a nuisance will have much larger problems to adjust to the necessities of demographic change compared to a society with high work ethics. 


\section{Das Wichtigste in Kürze}

Reformen wie die Einführung eines höheren Rentenalters sind denkbar unpopulär, obwohl sie angesichts der demografischen Entwicklung unausweichlich erscheinen. Reformpolitisch ist ein besseres Verständnis solcher Reformwiderstände wünschenswert. Bisherige Untersuchungen haben dabei vor allem den Einfluss sozioökonomischer Charakteristika, wie z. B. Geschlecht, Alter oder Einkommen, sowie den Informationsstand der Individuen in den Blick genommen. Faktoren, die mit den individuellen Arbeitspräferenzen zusammenhängen, wurden hingegen bislang vernachlässigt. Dieser Beitrag untersucht daher die Rolle der intrinsischen Arbeitsmotivation zur Erklärung von Reformpräferenzen. Solche nicht-monetären Arbeitsanreize sollten in einer umfassenden Analyse von Reformwiderständen berücksichtigt werden. So ist zu erwarten, dass Menschen mit hoher intrinsischer Motivation einen geringeren Nutzenverlust durch eine Anhebung des Renteneintrittsalters erfahren als Personen, die Arbeit als eine große Last empfinden.

Wir betrachten dazu zunächst die Bildung von individuellen Rentenreformpräferenzen im Rahmen einer optimalen Arbeits-/Rentenentscheidung (,job separation decision“). Demnach sollte für ein Individuum mit hoher intrinsischer Motivation eine Anhebung des Renteneintrittsalters eine relativ attraktive Reformoption im Vergleich zu den Alternativen einer Rentenkürzung oder höherer Rentenbeiträge sein.

Wir testen diese Hypothese anhand repräsentativer Daten der Allgemeinen Bevölkerungsumfrage der Sozialwissenschaften (ALLBUS). Dabei erweist sich eine hohe intrinsische Arbeitsmotivation als eine robuste Determinante individueller Rentenreformpräferenzen. Unser Ergebnis ergänzt somit die Literatur zur intrinsischen Motivation und trägt ebenfalls zu einem verbesserten Verständnis von Reformprozessen und deren Determinanten bei. Während die Bedeutung intrinsischer Arbeitsmotivation bislang lediglich vor dem Hintergrund der Effizienz von Organisationen bzw. Unternehmen betrachtet wurde, belegen unsere Ergebnisse ihren Einfluss in der Bildung wirtschaftspolitischer Präferenzen. Fehlende nicht-monetäre Anreize treiben demnach den Widerstand gegenüber Reformen, die einen höheren Arbeitseinsatz erfordern. Gesellschaften, in denen Arbeit vorwiegend als Last wahrgenommen wird, stehen daher vor größeren Schwierigkeiten den Herausforderungen des demografischen Wandels gerecht zu werden als Gesellschaften mit einer hohen Arbeitsethik. 


\title{
Intrinsic Work Motivation and
}

\section{Pension Reform Acceptance}

\author{
Friedrich Heinemann* (ZEW Mannheim and University of Heidelberg) \\ Tanja Hennighausen (ZEW Mannheim and University of Mannheim) \\ Marc-Daniel Moessinger (ZEW Mannheim)
}

June 2011

\begin{abstract}
Although demographic change leaves pay-as-you-go pension systems unsustainable, reforms, such as a higher pension age, are highly unpopular. This contribution looks into the role of intrinsic motivation as a driver for pension reform acceptance. Theoretical reasoning suggests that this driver should be relevant: The choice among different pension reform options (increasing pension age, increasing contributions, cutting pensions) can be analyzed within the framework of an optimal job separation decision. In this optimization, intrinsic job satisfaction matters as it decreases the subjective costs of a higher pension age. We test this key hypothesis on the basis of the German General Social Survey (ALLBUS). The results are unambiguous: In addition to factors such as age or education, the inclusion of intrinsic work motivation helps to improve our prediction of an individual's reform orientation. Our results are of importance for reform acceptance beyond the specific topic of pension reform. They point to the fact that the support for welfare state reform is also decided at the workplace.
\end{abstract}

JEL Classification Code: D78, H55, H31

Keywords: pension system, reforms, pension age, ALLBUS

*Corresponding author

Friedrich Heinemann

Centre for European Economic Research (ZEW)

L7, 1

68161 Mannheim

Germany

+49-621-1235 149

Heinemann@zew.de 


\section{Introduction}

Adjusting the structures of developed welfare states to population ageing remains one of the key challenges of economic policy in many industrial countries. Notwithstanding these necessities, reform options such as a higher pension age are unpopular among the majority of voters albeit with substantial individual heterogeneity. Preceding studies have explored numerous important drivers of pension reform acceptance. According to these insights, an individual's socio-economic characteristics like gender, income or age matter as does the degree of information on the extent of the system imbalances. So far, however, the literature has not looked into another potential source of reform resistance which is related to an individual's (dis-) utility from work. Hence, this contribution argues that intrinsic motivation, which has received increasing attention on other fields of economic analysis, must not be overlooked in a comprehensive analysis of pension reform preferences. Pension reforms impose or reduce restrictions on ageing citizens to offer their work at the labor market. Therefore, an individual's work motivation should have an impact on reform preferences. People with intrinsic work motivation will be less anxious about longer working years compared to people for whom work is a burden.

To specify the theoretical link between work motivation and pension reform acceptance, we regard the formation of pension age preferences within the framework of an optimal job separation decision. In this context, the pension regime offers an outside option to the continuation of work and co-determines a reservation wage. If the older worker's job does not pay the reservation wage, the pension regime is more attractive. Intrinsic work motivation will, ceteris paribus, lower this reservation wage whereas someone with a large disutility from work will demand a higher compensation for staying in employment. Therefore, a higher pension age should be a relatively attractive reform option for intrinsically motivated workers compared to the reform alternatives of cutting pensions or increasing contributions.

In the empirical part, this prediction is tested for data from the representative ALLBUS survey (German General Social Survey) of the German population. This test adds to the scarce literature on the drivers of pension reform acceptance (surveyed below) in at least two respects. First, it is innovative as to the inclusion of intrinsic motivation and job satisfaction as a potential determinant of reform acceptance. As such, it also advances the intrinsic motivation literature, which, so far, is unrelated to the formation of policy preferences. Second, it does not look at pension reform in general but differentiates between three distinct reform options and their relative popularity: Cutting pensions, increasing contributions and lifting the pension 
age. The results strongly confirm that (lacking) intrinsic work motivation is a robust determinant for individual (resistance and) support for a higher pension age. A reversed effect is observable with respect to the support for higher pension contributions: Intrinsically motivated individuals are less than others willing to pay the price for early retirement through higher contributions.

Our results indicate that intrinsic motivation is relevant for certain economic policy preferences as well, a finding which enriches the literature on intrinsic motivation by one important application. Non-monetary work incentives appear to be not only important for individual productivity or an organization's efficiency but also for a country's institutional adaptability. The findings point to the fact that the support for welfare state reforms is also decided at the workplace.

The paper's structure is as follows: Section 2 briefly surveys the literature on both the drivers of pension reform acceptance and the role of intrinsic motivation in economic contexts. Section 3 derives the theoretical expectations to which extent intrinsic work motivation should impact on different pension reform options. The data and empirical results are presented in sections 4 and 5 followed by robustness checks and conclusions on the feasibility of pension reforms.

\section{Literature survey}

\subsection{Pension reform preferences}

The existing scarce literature on the drivers of pension reform acceptance has successfully shed light on some important aspects. Individuals’ socio-economic characteristics help to explain variation: The young are more reform oriented than the old; males more than females; the rich more than the poor (Boeri et al., 2001, 2002). Much of this variation is obviously consistent with a self-interest view on the welfare state along the lines of Meltzer and Richard (1981) where voters judge welfare arrangements on the basis of their individual monetary net balance. Women (due to longer life expectation compared to men), the old (due to their more limited time horizon compared to the young), and the poor (due to the redistributive elements in pay-as-you-go systems and due to a larger unemployment risk compared to the rich) are relative winners of the status quo. Consistently, all these groups show a relative low inclination to accept reforms which cut back pensions or lift pension age. Scheubel et al. (2009) expand the standard set of self-interest related determinants to the individually expected work 
ability at pension age and show that this expectation significantly drives the rejection of a higher retirement age.

A further insight from this literature is that, beyond self-interest, information matters. Boeri et al. (2001, 2002) show for a survey of European citizens that they underestimate the costs of the system and have an unrealistic expectation of benefits. The better voters are informed, the more they support reforms which would allow for a partial opting out of mandatory pay-asyou-go systems towards private funded schemes. For Italian survey data, Boeri and Tabellini (2010) find that voters are vastly uninformed about the cost and functioning of the pension system and that the degree of information helps to predict an individual's readiness to accept reforms. However, even better information does not guarantee support for sustainability improving reforms. Generally, reforms which cut back the size of pay-as-you-go systems lack support, even among those who are informed about an imminent pension crisis (Boeri et al., 2002).

In addition to self-interest and information related factors, the non-economic approaches stress that individual ideological views contribute to shape pension reform preferences. For example, Lynch and Myrskylä (2009) exploit Eurobarometer data to demonstrate that ideological proxies, such as general views on the welfare state or union membership, significantly influence individual positions on pension reforms. In a macro cross-national study, Schneider (2009) confirms that trade union power reduces the likelihood of pension reforms. At the same time, the objective reform need, measured on the basis of projected pension spending increases, speeds up reform activity.

The existing literature is focused on the acceptance of pension reforms in general without paying particular attention to the drivers of relative popularity of different pension reform options. Yet, Boeri et al. (2002) present descriptive evidence for this relative attractiveness for their two country study. According to these results, a higher pension age is more attractive in Italy than in Germany with the reversed pattern for cutting pensions.

None of the existing approaches have, however, included an individual's utility or disutility from work. Thus, the picture remains incomplete. 


\subsection{Intrinsic motivation}

The key contribution of the intrinsic motivation literature to economics is its widening of the perspective on incentives. Deci's definition is as follows: “One is said to be intrinsically motivated to perform an activity when one receives no apparent reward except the activity itself” (Deci, 1971: p. 105). Whereas, in particular in the context of principal-agent relationships, neoclassical economics has stressed the role of monetary or other extrinsic incentives, the intrinsic motivation literature corrects this unbalanced view.

One insight of the literature is that monetary incentives or punishment might even be counterproductive as these externally set constraints may crowd out intrinsic motivation (Bénabou and Tirole, 2003, 2006). The empirical evidence is manifold and ranges from experiments, where incentives crowd out reciprocity, over tax honesty, where fines may lead to lower tax morale, up to labor supply decisions, where the introduction of small monetary incentives for voluntary works may reduce supply or labor efficiency (Frey and Jegen, 2001; Frey, 2008). The existence of this second type of motivation has become important for modern economics' advice on optimum institutions. For instance, the conclusions relate to optimal organizational forms of modern companies with respect to an optimal balance of extrinsic and intrinsic motivation to solve social dilemmas (Osterloh et al., 2002) or to the design of optimal knowledge transfer (Osterloh and Frey, 2000).

Job satisfaction and intrinsic motivation are fostered by similar determinants and are mutually reinforcing. The literature on job satisfaction identifies determinants like autonomy, social relationships (at the work place), advancement opportunities, status and the absence of physical strain (Cornelißen, 2006); for a survey see Diaz-Serrano and Cabral Vieira (2005). Frey (1997a) has pointed out that intrinsic motivation rises the more interesting the task, the more personalized the principal-agent relationship and the greater the involvement of the agent is. For this reason, there is a strong link between intrinsic motivation and job satisfaction. In the following, we are not interested to disentangle this complex so we use both terms in an interchangeable way.

Although the relevance of intrinsic motivation has thus been established in numerous contexts, there is one striking gap: So far, this concept has not been related to the formation of policy preferences. We aim at filling this gap in the context of pension reform acceptance - a field particularly promising since it is about government interference with individual freedom of choice to end working life. 


\section{Theoretical expectations}

Intuitively, there should be a link between pension reform preferences and intrinsic motivation. Somebody who obtains large intrinsic rewards from work should be more relaxed about a later pension age compared to somebody doing it "just for the money".

To analyze the impact of intrinsic work motivation on pension reform preference in a more precise way, it is useful to look at the preferred retirement age in the context of an optimizing job separation decision. ${ }^{1}$ The job separation literature assumes that it is optimal for both employers and employees that a worker leaves a firm whenever outside opportunities offer a more productive employment (Mortensen, 1978). Certainly, when reflecting retirement, the outside option is of a different nature and does not relate to the productivity (and wage) which can be achieved with another employer. This reflection, nevertheless, relates to another type of outside option which offers a pension in combination with increased leisure consumption. The combined features of this outside option (including factors such as wealth or non-labor income) determine an older worker's reservation wage. Only if labor income for a given age still exceeds the reservation wage associated with the pension outside option, an individual will prefer work over retirement. Ceteris paribus, workers with a large disutility from work will have a higher reservation wage and a preference to retire earlier than those with moderate disutility or even positive utility from work. There is considerable evidence that individual retirement decisions are indeed heavily influenced by job satisfaction and working conditions (Blekesaune and Solem, 2005, and the survey in there) so that it appears promising to assume a similar link for the formation of preferences on pension reforms. ${ }^{2}$

However, preference formation on pension reform options is more complex than an individual retirement decision. For the latter, it is merely the adjustment to the incentives of an exogenously given pension system. For the former, it is the reasoning on parameter changes which would serve the individual utility best over the (rest of one's) life cycle.

The challenge for a static pay-as-you-go pension system which is not adjusted to an increase in longevity is that, in the beginning of a representative insured's life cycle, his present value

\footnotetext{
${ }^{1}$ Filer and Honig (2005) suggest this analogy for their analysis of endogenous retirement and (private) pension decisions.

2 The literature, according to which monetary early retirement incentives (e.g. through pension cuts for early retirement which are too small compared to an actuarially fair cut) are highly effective (see Gruber and Wise (2004, 2007) and Börsch-Supan et al. (2004; 2007)), does not falsify the possible impact of intrinsic work motivation on retirement preferences. None of these studies has analyzed to which extent intrinsic work motivation proxies have had a significant impact.
} 
of received pensions, $P V P$, exceeds his present value of contributions, $P V C$, with the implicit individual pension debt, $I D=P V P-P V C .^{3}$ This development leaves the system unsustainable. A reform which wants to restore sustainability would have to cut the ID back to zero. Basically, this adjustment can occur through changing one of three parameters (or some of them in combination): Increasing pension contributions, cutting pensions or lifting retirement age.

No matter how the adjustment occurs, a representative worker at the beginning of his working life will experience a loss of lifetime income from the pension reform which equals ID. This is the necessary cut any reform package which targets at restoring systemic sustainability has to deliver. Thus, the pension reform options do not differ with respect to their negative income effects over a complete life cycle.

In spite of an identical income effect (from the perspective of the beginning of working life), the reform options would translate differently into individual utility. For workers with a high disutility from labor, the higher retirement age will be particular unattractive since it confronts them with a substantial loss in leisure. The assessment is different for those with only low disutility or even utility from work in the sense that they even would prefer unpaid work over sitting at home. For the latter, the longer working lifetime is no loss but utility-enhancing. A higher pension age in these cases may also alleviate a binding constraint, which, so far, has prevented them from working beyond the pension age before the reform. ${ }^{4}$ This reform would then simply expand the leeway for self-determination, which again reinforces the importance of intrinsic motivation, which is particularly powerful in the absence of external restrictions (Frey, 1997b). Thus, there is the clear theoretical prediction that a higher pension age should be a reform option which is relative attractive for those with low work disutility compared to those suffering strongly from any additional working day.

We would not expect that intrinsic motivation impacts equally positively on the acceptance of lower pension payments or higher pension contributions. Both reform proposals are not associated with any increase in self-determination. Even if intrinsically motivated workers do not

\footnotetext{
${ }^{3}$ In addition, there is a problem from decreased fertility, which aggravates the mismatch between active workers' contributions and pensioners' benefits. This does, however, not change the subsequent reasoning qualitatively.

${ }^{4}$ For Germany, to which our empirical study applies, working beyond the pension age is legally possible without substantial economic disincentives (there are no cuts in pensions with additional active labor income). However, individual and collective work contracts regularly refer to the official pension age as to the age related contract end. Hence, the pension system's retirement age often imposes a de facto binding constraint on the retirement decision. An economic rationale for employers supporting this mandatory retirement age is given by Lazear's famous life cycle- and efficiency wage model (Lazear, 1979).
} 
work just for the money, they would not welcome new external interventions which cause resistance and crowd out intrinsic motivation (Frey, 1997a). While all three reform options (higher contributions, lower benefits, longer working years) confront workers with the same income effect $I D$, only the longer working years option increases the scope for selfdetermination and should, thus, be the favorite of people who enjoy their work.

This conceptual framework also allows identifying further essential determinants which should impact on pension reform preferences. In principle, all factors which influence older worker's reservation wage, such as wealth, health or non-labor income, should matter. Furthermore, the position within the life cycle is crucial (age effects have already been acknowledged in the literature, see above) since the income effect of a reform is only identical for representative individuals over their complete life cycle. For individuals at different stages in the life cycle, reform options are associated with different income effects. Thus, increasing pension contributions ( $P V C$ ) is relatively attractive for older workers and pensioners and unattractive for younger workers, who have to bear these higher contributions over their whole working life. ${ }^{5}$ Conversely, cutting pensions $(P V P)$ is relatively attractive for younger workers and less attractive for older workers or pensioners with the latter not benefitting at all from savings in contributions. A higher pension age which effectively cuts back $P V P$ is particularly unattractive for older workers ${ }^{6}$ and attractive for younger workers and even more for pensioners, who are past the age to be affected.

\section{The data}

For our empirical test we use data from the German General Social Survey (Terwey et al., 2007), which was first conducted in 1980 with subsequent waves every two years. ${ }^{7}$ The survey is designed to be representative for the German population and offers data on the individual labor market status, socio-economic characteristics and policy preferences. For our study, we make use of data collected from March to August 2006. In Germany, this period was characterized by a large public and parliamentary debate on the future of the pension system,

\footnotetext{
${ }^{5}$ Sinn and Übelmesser (2002) define the age dependent population split of supporters and opponents to a cutback of the pay-as-you-go system on that basis.

${ }^{6}$ This only holds if older workers are not protected by generous transitory arrangements, as it is the case for the very slow German phasing in of a higher pension age (from 65 to 67), which only becomes fully effective from the year 2029 onwards.

${ }^{7}$ For further information and data availability visit www.gesis.org/en/allbus/.
} 
which resulted in the decision to gradually increase the pension age with the relevant law taking effect in 2007.

This data base offers all necessary preconditions for testing for the impact of intrinsic motivation on the acceptance of pension reforms. Besides a rich coverage of socio-economic characteristics, it includes questions on the acceptance of the three basic pension reform options: A higher pension age, higher contributions to the pay-as-you-go system and lower pension payments. ${ }^{8}$ This specific type of question is particularly useful as it confronts respondents with different reform alternatives which are equally able to improve the sustainability of the payas-you-go system. Surveys which only ask for the acceptance or rejection of one reform option, such as a higher pension age, are confronted with the problem that results could rather reflect general reform willingness than the assessment of the specific reform option (Scheubel et al., 2009). With that ALLBUS question, this is less of a concern and we are able to measure the relative popularity of different reform options independent from the popularity of pension reforms in general.

The survey equally covers a set of questions which can be employed as indicators for the complex of intrinsic work motivation and job satisfaction. For instance, the survey participants answer the question whether they would like to stay employed even without need for the money earned or whether they are willing to work harder to support the organization. The precise questions run as follows: Our "like work" dummy represents the support for the statement "I would like to work even without need for the money" and the "work willingness" dummy marks individuals who declare "I am ready to work harder than I have to in order to contribute to my firm's/organization's success”. The first proxy corresponds closest to Deci's definition of intrinsic motivation (section 2.2) while the second refers rather to the loyalty to the specific employer and not so much to intrinsic work motivation in general.

Both the pension reform preference and the work willingness questions have been fed into the ALLBUS survey in the context of the International Social Survey Program (ISSP). ${ }^{9}$

\footnotetext{
${ }^{8}$ The precise question is as follows: "Currently there is a large discussion in Germany about pensions, the financing of pensions and pension age. Below you find three possible measures to solve the problems of the statutory pension system. If you had to decide for one of these, which one would you choose?” with the three answer options "To solve the problems of the statutory pension system, the pension age should be increased/ pension contributions should be increased/ the statutory pensions should be cut”. An overview on all variable definitions including ALLBUS-code is given in the appendix.

${ }^{9}$ The ALLBUS program is promoted by DFG (German Research Society) and GESIS (Institute for Social Science), which also conduct the German part of the International Social Survey Program (ISSP). The latter program was firstly implemented in 1985 and annually collects data for various themes of social science.
} 
The descriptive statistics (Table 1) confirm the finding from other studies that a higher pension age is not a popular solution. If they had to accept one reform, the survey respondents would rather opt for higher contributions. The least popular reform is, however, cutting pensions. According to our intrinsic motivation proxies, around two thirds classify as intrinsically motivated in the sense that they do not work primarily for the money. About one third is ready to work hard for their company to improve the company's success.

Table 1: Descriptive statistics

\begin{tabular}{|l|l|l|l|l|l|}
\hline Variable & Obs. & Mean & Std. Dev. & Min & Max \\
\hline \multicolumn{5}{|c|}{ Pension reform preference } \\
\hline Increase pension age & 1295 & 0.2672 & 0.4427 & 0 & 1 \\
\hline Higher contributions & 1295 & 0.5606 & 0.4965 & 0 & 1 \\
\hline Cutting pensions & 1295 & 0.1722 & 0.3777 & 0 & 1 \\
\hline \multicolumn{7}{|l|}{ Controls } \\
\hline Age $<25$ & 1293 & 0.1036 & 0.3049 & 0 & 1 \\
\hline Age $>=25,<45$ & 1293 & 0.3434 & 0.4750 & 0 & 1 \\
\hline Age $>=45,<65$ & 1293 & 0.3372 & 0.4729 & 0 & 1 \\
\hline Age $>=65$ & 1142 & 0.3853 & 0.4869 & 0 & 1 \\
\hline Youth in East & 1293 & 0.1237 & 0.3294 & 0 & 1 \\
\hline Member of union & 1293 & 0.3016 & 0.4591 & 0 & 1 \\
\hline Policy interest & 1295 & 0.5058 & 0.5002 & 0 & 1 \\
\hline Female & 1293 & 0.1036 & 0.3049 & 0 & 1 \\
\hline Job insecure & 1295 & 0.0718 & 0.2583 & 0 & 1 \\
\hline University & 1284 & 0.1550 & 0.3620 & 0 & 1 \\
\hline Unemployed & 1295 & 0.0819 & 0.2742 & 0 & 1 \\
\hline Not employed & 1295 & 0.5012 & 0.5002 & 0 & 1 \\
\hline Sick & 1295 & 0.1560 & 0.3630 & 0 & 1 \\
\hline Married & 1295 & 0.5714 & 0.4951 & 0 & 1 \\
\hline Civil servant & 1295 & 0.0347 & 0.1832 & 0 & 1 \\
\hline Entrepreneur & 1295 & 0.0533 & 0.2247 & 0 & 1 \\
\hline & Proxies intrinsic motivation & \\
\hline Like work & 1219 & 0.6957 & 0.4603 & 0 & 1 \\
\hline Work willingness & 1295 & 0.3629 & 0.4810 & 0 & 1 \\
\hline
\end{tabular}

\section{Econometric testing}

In a first step, we model the formation of reform preferences as an independent decision problem over acceptance or rejection of each single option under consideration. Hence, our dependent variable is binary ( 1 support for the specific reform option, 0 no support) and we apply a probit estimation procedure for each of the three policy options (“increase pension age”, "higher contributions”, “cutting pensions”). In the next step, we proceed to a multinomial 
logit modelling, which allows identifying the drivers of relative probabilities between the available reform options.

The inclusion of control variables is guided by our theoretical reasoning. The position in the life cycle should impact on policy preferences as explained above so that we include different age class dummies $(<25,25-44$, and $45-64$ years with the pensioner age class 65 and older as our point of reference). Furthermore, we account for individual characteristics which should affect the reservation wage required to opt for longer working years instead of retirement. Among these indicators, we include the fear of a job loss, the employment status (unemployed and not employed $)^{10}$ and sickness. All these factors should push up the reservation wage for work in a higher age and, thus, render an early pension as highly desirable. Given the importance of information on pension reform acceptance (see the literature survey above), we include an information proxy based on self-assessment (respondent claims that he is interested in politics in general). The dummy for university education is an integrated proxy for different facets: The degree of information, job satisfaction, but also accumulated wealth - at least the latter two factors should lead to a lower reservation wage and a relatively favorable position on a higher pension age. We also add control variables which are normally used for modelling policy preferences, e.g. in the context of redistribution (youth in east, Alesina and FuchsSchündeln, 2007; union membership). Finally, we supplement standard socio-economic (gender, married) and employment related indicators (entrepreneur, civil servant). ${ }^{11}$

Tables 2 to 4 present the probit estimation results. For each of the policy options the baseline including the controls as explained is estimated followed by specifications including the proposed intrinsic motivation indicators consecutively.

With respect to the general controls, the included proxies confirm our expectation if they are significant: The active workers are less willing to accept higher pension ages compared to those who already receive pensions (the respondents aged 65 and above are the reference group, which was dropped in the regression). Conversely, the working age cohorts are more inclined to cut pension payments than today's pensioners. Interestingly, these effects appear to be stronger for the middle aged compared to the very young. Among the other controls,

\footnotetext{
${ }^{10}$ We distinguish between people who are currently unemployed and people not working due to other reasons such as maternity, education or disability.

${ }^{11}$ ALLBUS also includes an income variable, which, however, suffers from numerous missing values. An inclusion did not change any of the central results but came at the price of a serious loss in observations. Theory would also point to the importance of wealth proxies for older age reservation wages. Suitable wealth indicators are not available in the ALLBUS survey.
} 
“youth in East”, “policy interest”, “university” and "sick” all prove to be significant in most specifications (apart from cutting pension estimations). The signs are as expected: The sick, those with youth in the East, without particular interest in politics or without university education are less ready to opt for a higher pension age, but prefer higher contributions instead. The self-employed differ significantly only with respect to the contribution preference where they reject higher contributions. Compared to men, women are more critical of cutting pensions.

The augmentation of the baselines by our intrinsic work motivation proxies leads to significant results for the "like work" and the "work willingness" dummy. The impact of intrinsic motivation is as expected: Respondents who would prefer work over leisure even without need for the money have a higher probability to support a higher pension age and are less likely to opt for higher contributions. The marginal effect allows quantifying the effect: The probability that a respondent opts for a higher pension age is 7.8 percentage points higher if this person is intrinsically motivated. The loyalty related proxy "work willingness", however, has a smaller impact (4.8 percentage points) and fails to be significant at conventional levels.

A limitation of the binary approach is that the resulting separate regressions for each of the three single reform options do not allow for the cross-equation links. This implies inefficient testing given that, by construction of the pension reform question in the ALLBUS survey, the answers are dependent. Hence, a multinomial logit is a more efficient estimation approach. This procedure allows estimating the impact of covariates on the relative probabilities of an individual choosing one of two options. Since the pension reform preference variable has three values, it implies the joint estimation of two equations. Tables 5, 6 and 8 present the results. The base outcome is the increase of pension age. The relative risk representation is chosen; i.e. the coefficients represent a covariate's impact on the relative probability that one of two reform options is preferred. The baseline is followed by specifications augmented by each of the intrinsic motivation proxies consecutively. Tables 7 and 9 include the predicted probabilities of an individual to opt for each of the three reform options depending on its intrinsic motivation (and at mean values for the other control variables).

The results for the multinomial logit estimations show some differences to the probit results. Generally, a more critical screening is required since less control variables keep their significance. For instance, the gender variable loses its significance. The age effects are confirmed: Active workers are much more likely to opt for lower pensions than for a higher pension age (factor 4.6 for the 25-44 age group). An absent university education, a youth in the East and 
no particular interest in politics are robustly significant and foster a rejection of higher pension ages relative to the other solutions.

The intrinsic motivation indicators survive the multinomial testing. As for the probit analysis, the "like work" and the "work willingness" proxies turn out to have a significant effect. Intrinsic motivation along these two dimensions increases the probability that an individual will opt for a higher pension age. The predicted probabilities in Tables 7 and 9 report the size of the effect. These predictions are calculated for average values of all other covariates and show the difference between probabilities for respondents who are and who are not intrinsically motivated. For those who would work even without the need for the money earned, the crucial difference is related to a higher probability of opting for higher pension age and a lower probability of opting for higher contributions. No marked difference exists for the cutting pension preference. For the second significant intrinsic motivation proxy, the willingness to work hard for the company, a particular marked difference exists for the cutting pension preference. Those who feel a large loyalty to their firm or organization are less likely to opt for lower pensions. 
Table 2: Probit estimation, dependent variable: increase of pension age preference

\begin{tabular}{|c|c|c|c|}
\hline & (1) & $(2)$ & (3) \\
\hline \multirow[t]{2}{*}{ Age $<25$} & -0.0423 & -0.0457 & -0.0516 \\
\hline & [0.0529] & {$[0.0541]$} & [0.0522] \\
\hline \multirow[t]{2}{*}{ Age $>=25,<45$} & $-0.0998 * *$ & $-0.0953^{* *}$ & $-0.110^{* *}$ \\
\hline & {$[0.0426]$} & {$[0.0440]$} & [0.0428] \\
\hline \multirow[t]{2}{*}{ Age $>=45,<65$} & -0.0623 & -0.0677 & $-0.0677^{*}$ \\
\hline & [0.0405] & [0.0417] & [0.0405] \\
\hline \multirow[t]{2}{*}{ Youth in East } & $-0.125^{* * *}$ & $-0.128 * * *$ & $-0.126 * * *$ \\
\hline & {$[0.0260]$} & [0.0265] & {$[0.0260]$} \\
\hline \multirow[t]{2}{*}{ Member of union } & 0.0327 & 0.0399 & 0.0316 \\
\hline & [0.0416] & [0.0430] & [0.0416] \\
\hline \multirow[t]{2}{*}{ Policy interest } & $0.114 * * *$ & $0.105^{* * *}$ & $0.111 * * *$ \\
\hline & [0.0313] & {$[0.0320]$} & [0.0313] \\
\hline \multirow[t]{2}{*}{ Female } & 0.0161 & 0.00627 & 0.0157 \\
\hline & [0.0276] & [0.0282] & [0.0276] \\
\hline \multirow[t]{2}{*}{ Job insecure } & -0.0654 & -0.0529 & -0.0596 \\
\hline & {$[0.0540]$} & {$[0.0552]$} & {$[0.0550]$} \\
\hline \multirow[t]{2}{*}{ University } & $0.122 * * *$ & $0.133^{* * *}$ & $0.123 * * *$ \\
\hline & [0.0419] & [0.0434] & [0.0419] \\
\hline \multirow[t]{2}{*}{ Unemployed } & -0.000321 & -0.00377 & 0.00593 \\
\hline & [0.0569] & {$[0.0591]$} & {$[0.0577]$} \\
\hline \multirow[t]{2}{*}{ Not employed } & 0.0603 & $0.0750^{*}$ & $0.0840 * *$ \\
\hline & {$[0.0378]$} & [0.0385] & [0.0417] \\
\hline \multirow[t]{2}{*}{ Sick } & $-0.0746 * *$ & $-0.0946 * * *$ & $-0.0732 * *$ \\
\hline & [0.0348] & {$[0.0342]$} & [0.0349] \\
\hline \multirow[t]{2}{*}{ Married } & 0.0282 & 0.0298 & 0.0267 \\
\hline & [0.0290] & {$[0.0301]$} & {$[0.0290]$} \\
\hline \multirow[t]{2}{*}{ Civil servant } & -0.0600 & -0.0813 & -0.0577 \\
\hline & [0.0636] & [0.0596] & [0.0642] \\
\hline \multirow[t]{2}{*}{ Entrepreneur } & 0.103 & 0.104 & 0.0961 \\
\hline & {$[0.0684]$} & {$[0.0694]$} & {$[0.0680]$} \\
\hline \multicolumn{4}{|c|}{ Proxy intrinsic motivation } \\
\hline \multirow[t]{2}{*}{ Like work } & & $0.0785^{* * *}$ & \\
\hline & & {$[0.0284]$} & \\
\hline \multirow[t]{2}{*}{ Work willingness } & & & 0.0485 \\
\hline & & & {$[0.0363]$} \\
\hline Observations & 1127 & 1068 & 1127 \\
\hline Pseudo $\mathrm{R}^{2}$ & 0.0660 & 0.0740 & 0.0674 \\
\hline
\end{tabular}

Marginal effects, standard errors in brackets.

*** $\mathrm{p}<0.01,{ }^{* *} \mathrm{p}<0.05,{ }^{*} \mathrm{p}<0.1$ 
Table 3: Probit estimation, dependent variable: higher contribution preference

\begin{tabular}{|c|c|c|c|}
\hline & (1) & $(2)$ & (3) \\
\hline \multirow[t]{2}{*}{ Age $<25$} & 0.00775 & 0.0295 & -0.00385 \\
\hline & [0.0667] & {$[0.0690]$} & {$[0.0675]$} \\
\hline \multirow[t]{2}{*}{ Age $>=25,<45$} & -0.0459 & -0.0409 & -0.0578 \\
\hline & [0.0544] & {$[0.0565]$} & [0.0551] \\
\hline \multirow[t]{2}{*}{ Age $>=45,<65$} & -0.0222 & -0.0106 & -0.0290 \\
\hline & [0.0503] & {$[0.0527]$} & {$[0.0506]$} \\
\hline \multirow[t]{2}{*}{ Youth in East } & $0.0801^{* * *}$ & $0.0762 * *$ & $0.0783 * *$ \\
\hline & {$[0.0310]$} & {$[0.0321]$} & {$[0.0311]$} \\
\hline \multirow[t]{2}{*}{ Member of union } & -0.0583 & -0.0524 & -0.0589 \\
\hline & [0.0463] & [0.0475] & [0.0463] \\
\hline \multirow[t]{2}{*}{ Policy interest } & $-0.101 * * *$ & $-0.0902^{* *}$ & $-0.104 * * *$ \\
\hline & {$[0.0345]$} & {$[0.0357]$} & [0.0346] \\
\hline \multirow[t]{2}{*}{ Female } & 0.0380 & 0.0443 & 0.0370 \\
\hline & [0.0313] & [0.0324] & [0.0314] \\
\hline \multirow[t]{2}{*}{ Job insecure } & 0.0913 & 0.0823 & 0.0991 \\
\hline & [0.0608] & [0.0618] & [0.0608] \\
\hline \multirow[t]{2}{*}{ University } & $-0.115^{* *}$ & $-0.131 * * *$ & $-0.115^{* *}$ \\
\hline & [0.0449] & [0.0465] & [0.0449] \\
\hline \multirow[t]{2}{*}{ Unemployed } & -0.0166 & -0.0337 & -0.0102 \\
\hline & {$[0.0643]$} & {$[0.0676]$} & {$[0.0643]$} \\
\hline \multirow[t]{2}{*}{ Not employed } & -0.0291 & -0.0314 & -0.00240 \\
\hline & [0.0432] & {$[0.0443]$} & {$[0.0472]$} \\
\hline \multirow[t]{2}{*}{ Sick } & $0.124 * * *$ & $0.144 * * *$ & $0.125^{* * *}$ \\
\hline & {$[0.0424]$} & [0.0433] & {$[0.0423]$} \\
\hline \multirow[t]{2}{*}{ Married } & -0.0114 & -0.00783 & -0.0129 \\
\hline & [0.0333] & {$[0.0348]$} & [0.0333] \\
\hline \multirow[t]{2}{*}{ Civil servant } & 0.0695 & 0.0927 & 0.0735 \\
\hline & [0.0804] & [0.0798] & {$[0.0802]$} \\
\hline \multirow[t]{2}{*}{ Entrepreneur } & $-0.153^{* *}$ & $-0.159 * *$ & $-0.161^{* *}$ \\
\hline & [0.0709] & {$[0.0727]$} & {$[0.0710]$} \\
\hline \multicolumn{4}{|c|}{ Proxy intrinsic motivation } \\
\hline \multirow[t]{2}{*}{ Like work } & & $-0.0673^{*}$ & \\
\hline & & {$[0.0346]$} & \\
\hline \multirow[t]{2}{*}{ Work willingness } & & & 0.0553 \\
\hline & & & [0.0390] \\
\hline Observations & 1127 & 1068 & 1127 \\
\hline Pseudo $\mathrm{R}^{2}$ & 0.0391 & 0.0435 & 0.0404 \\
\hline
\end{tabular}

Marginal effects, standard errors in brackets.

*** $\mathrm{p}<0.01,{ }^{* *} \mathrm{p}<0.05,{ }^{*} \mathrm{p}<0.1$ 
Table 4: Probit estimation, dependent variable: cutting pension preference

\begin{tabular}{|c|c|c|c|}
\hline & $(1)$ & $(2)$ & $(3)$ \\
\hline \multirow[t]{2}{*}{ Age $<25$} & 0.0775 & 0.0472 & 0.0978 \\
\hline & {$[0.0658]$} & {$[0.0651]$} & {$[0.0685]$} \\
\hline \multirow[t]{2}{*}{ Age $>=25,<45$} & $0.185^{* * *}$ & $0.169 * * *$ & $0.205 * * *$ \\
\hline & {$[0.0520]$} & {$[0.0535]$} & [0.0528] \\
\hline \multirow[t]{2}{*}{ Age $>=45,<65$} & $0.126 * * *$ & $0.115^{* *}$ & $0.137 * * *$ \\
\hline & {$[0.0472]$} & [0.0495] & {$[0.0474]$} \\
\hline \multirow[t]{2}{*}{ Youth in East } & $0.0447^{*}$ & $0.0516 * *$ & $0.0484 * *$ \\
\hline & [0.0236] & {$[0.0247]$} & {$[0.0237]$} \\
\hline \multirow[t]{2}{*}{ Member of union } & 0.0294 & 0.0165 & 0.0296 \\
\hline & [0.0347] & [0.0353] & [0.0348] \\
\hline \multirow[t]{2}{*}{ Policy interest } & -0.0118 & -0.0115 & -0.00593 \\
\hline & [0.0248] & [0.0259] & [0.0250] \\
\hline \multirow[t]{2}{*}{ Female } & $-0.0461^{* *}$ & $-0.0416^{*}$ & $-0.0438 *$ \\
\hline & {$[0.0229]$} & {$[0.0240]$} & [0.0229] \\
\hline \multirow[t]{2}{*}{ Job insecure } & -0.0372 & -0.0386 & -0.0473 \\
\hline & [0.0382] & [0.0393] & {$[0.0366]$} \\
\hline \multirow[t]{2}{*}{ University } & -0.00311 & -0.00213 & -0.00293 \\
\hline & [0.0323] & [0.0338] & {$[0.0321]$} \\
\hline \multirow[t]{2}{*}{ Unemployed } & 0.0176 & 0.0394 & 0.00820 \\
\hline & [0.0489] & {$[0.0546]$} & {$[0.0472]$} \\
\hline \multirow[t]{2}{*}{ Not employed } & -0.0333 & -0.0474 & $-0.0689 * *$ \\
\hline & [0.0312] & [0.0325] & {$[0.0331]$} \\
\hline \multirow[t]{2}{*}{ Sick } & -0.0446 & -0.0418 & -0.0462 \\
\hline & [0.0312] & {$[0.0330]$} & [0.0308] \\
\hline \multirow[t]{2}{*}{ Married } & -0.0158 & -0.0225 & -0.0139 \\
\hline & [0.0244] & {$[0.0258]$} & [0.0243] \\
\hline \multirow[t]{2}{*}{ Civil servant } & -0.00940 & -0.00757 & -0.0152 \\
\hline & {$[0.0550]$} & {$[0.0571]$} & {$[0.0536]$} \\
\hline \multirow[t]{2}{*}{ Entrepreneur } & 0.0386 & 0.0437 & 0.0561 \\
\hline & {$[0.0530]$} & {$[0.0555]$} & {$[0.0556]$} \\
\hline \multicolumn{4}{|c|}{ Proxy intrinsic motivation } \\
\hline \multirow[t]{2}{*}{ Like work } & & -0.00811 & \\
\hline & & {$[0.0265]$} & \\
\hline \multirow[t]{2}{*}{ Work willingness } & & & $-0.0767 * * *$ \\
\hline & & & {$[0.0248]$} \\
\hline Observations & 1,127 & 1,068 & 1,127 \\
\hline Pseudo $\mathrm{R}^{2}$ & 0.0515 & 0.0513 & 0.0601 \\
\hline
\end{tabular}

Marginal effects, standard errors in brackets.

$* * * \mathrm{p}<0.01, * * \mathrm{p}<0.05,{ }^{*} \mathrm{p}<0.1$ 
Table 5: Multinomial logit estimation - baseline

\begin{tabular}{|c|c|c|}
\hline & Higher contributions & Cutting pensions \\
\hline \multirow[t]{2}{*}{ Age $<25$} & 1.1725 & 2.0104 \\
\hline & {$[0.3726]$} & [0.9749] \\
\hline \multirow[t]{2}{*}{ Age $>=25,<45$} & 1.3731 & $4.5571 * * *$ \\
\hline & [0.3529] & {$[1.7935]$} \\
\hline \multirow[t]{2}{*}{ Age $>=45,<65$} & 1.2117 & $2.9295 * *$ \\
\hline & [0.2818] & [1.0937] \\
\hline \multirow[t]{2}{*}{ Youth in East } & $1.9956 * * *$ & $2.2556 * * *$ \\
\hline & {$[0.3228]$} & {$[0.4631]$} \\
\hline \multirow[t]{2}{*}{ Member of union } & 0.7974 & 1.0269 \\
\hline & {$[0.1781]$} & {$[0.2842]$} \\
\hline \multirow[t]{2}{*}{ Policy interest } & $0.5484 * * *$ & $0.6150 *$ \\
\hline & {$[0.0892]$} & {$[0.1321]$} \\
\hline \multirow[t]{2}{*}{ Female } & 1.0107 & 0.7139 \\
\hline & {$[0.1560]$} & {$[0.1443]$} \\
\hline \multirow[t]{2}{*}{ Job insecure } & 1.6288 & 1.1463 \\
\hline & {$[0.6107]$} & [0.5132] \\
\hline \multirow[t]{2}{*}{ University } & $0.5225 * *$ & 0.6601 \\
\hline & {$[0.1071]$} & {$[0.1761]$} \\
\hline \multirow[t]{2}{*}{ Unemployed } & 0.9999 & 1.1784 \\
\hline & [0.3248] & {$[0.4817]$} \\
\hline \multirow[t]{2}{*}{ Not employed } & 0.7407 & 0.6413 \\
\hline & [0.1563] & [0.1773] \\
\hline \multirow[t]{2}{*}{ Sick } & $1.6562^{*}$ & 0.9847 \\
\hline & {$[0.3673]$} & [0.3233] \\
\hline \multirow[t]{2}{*}{ Married } & 0.8762 & 0.8155 \\
\hline & {$[0.1446]$} & {$[0.1731]$} \\
\hline \multirow[t]{2}{*}{ Civil servant } & 1.434 & 1.161 \\
\hline & [0.5900] & {$[0.5791]$} \\
\hline \multirow[t]{2}{*}{ Entrepreneur } & $0.4997 *$ & 0.8311 \\
\hline & {$[0.1704]$} & [0.3195] \\
\hline Observations & 1127 & \\
\hline Pseudo $\mathrm{R}^{2}$ & 0.0609 & \\
\hline chi2 & 133.6748 & \\
\hline $\mathrm{p}$ & 0.000 & \\
\hline
\end{tabular}

Base outcome: Increase of pension age, relative risk exposition. Standard errors in brackets.

$* * * \mathrm{p}<0.01, * * \mathrm{p}<0.05,{ }^{*} \mathrm{p}<0.1$ 
Table 6: Multinomial logit estimation - proxy: like work

\begin{tabular}{|c|c|c|}
\hline & Higher contributions & Cutting pensions \\
\hline \multirow[t]{2}{*}{ Age $<25$} & 1.2537 & 1.7491 \\
\hline & [0.4194] & {$[0.8857]$} \\
\hline \multirow[t]{2}{*}{ Age $>=25,<45$} & 1.3872 & $4.1020 * * *$ \\
\hline & [0.3733] & {$[1.6745]$} \\
\hline \multirow[t]{2}{*}{ Age $>=45,<65$} & 1.2864 & $2.8155^{* *}$ \\
\hline & {$[0.3174]$} & {$[1.0982]$} \\
\hline \multirow[t]{2}{*}{ Youth in East } & $2.0328 * * *$ & $2.3799 * * *$ \\
\hline & {$[0.3438]$} & {$[0.5030]$} \\
\hline \multirow[t]{2}{*}{ Member of union } & 0.7843 & 0.929 \\
\hline & {$[0.1816]$} & {$[0.2668]$} \\
\hline \multirow[t]{2}{*}{ Policy interest } & $0.5748 * *$ & $0.6300^{*}$ \\
\hline & {$[0.0975]$} & [0.1393] \\
\hline \multirow[t]{2}{*}{ Female } & 1.0525 & 0.7652 \\
\hline & [0.1693] & [0.1592] \\
\hline \multirow[t]{2}{*}{ Job insecure } & 1.519 & 1.079 \\
\hline & [0.5735] & {$[0.4852]$} \\
\hline \multirow[t]{2}{*}{ University } & $0.4860 * * *$ & 0.6384 \\
\hline & [0.1039] & {$[0.1746]$} \\
\hline \multirow[t]{2}{*}{ Unemployed } & 0.9756 & 1.319 \\
\hline & [0.3393] & {$[0.5652]$} \\
\hline \multirow[t]{2}{*}{ Not employed } & 0.6992 & $0.5594^{*}$ \\
\hline & {$[0.1520]$} & [0.1598] \\
\hline \multirow[t]{2}{*}{ Sick } & $1.9256^{* *}$ & 1.1456 \\
\hline & {$[0.4582]$} & {$[0.3896]$} \\
\hline \multirow[t]{2}{*}{ Married } & 0.8772 & 0.7829 \\
\hline & [0.1538] & {$[0.1726]$} \\
\hline \multirow[t]{2}{*}{ Civil servant } & 1.6761 & 1.3134 \\
\hline & {$[0.7116]$} & [0.6697] \\
\hline \multirow[t]{2}{*}{ Entrepreneur } & $0.4891^{*}$ & 0.8461 \\
\hline & [0.1724] & [0.3298] \\
\hline \multirow{3}{*}{ Like work } & roxy intrinsic motivati & \\
\hline & $0.6434^{*}$ & 0.6774 \\
\hline & [0.1152] & {$[0.1564]$} \\
\hline Observations & 1068 & \\
\hline Pseudo $\mathrm{R}^{2}$ & 0.0654 & \\
\hline chi2 & 136.3135 & \\
\hline $\mathrm{p}$ & 0.000 & \\
\hline
\end{tabular}

Base outcome: Increase of pension age, relative risk exposition. Standard errors in brackets. $* * * \mathrm{p}<0.01, * * \mathrm{p}<0.05, * \mathrm{p}<0.1$.

Table 7: Predicted probabilities (like work)

\begin{tabular}{|c|c|c|c|c|}
\cline { 3 - 5 } \multicolumn{2}{c|}{} & \multicolumn{3}{c|}{ Reform preference } \\
\cline { 3 - 5 } \multicolumn{2}{c|}{} & $\begin{array}{c}\text { Increase } \\
\text { pension age }\end{array}$ & $\begin{array}{c}\text { Higher } \\
\text { contributions }\end{array}$ & $\begin{array}{c}\text { Cutting } \\
\text { pensions }\end{array}$ \\
\hline \multirow{3}{*}{ Like work } & 0 & 0.1885 & 0.6389 & 0.1727 \\
\cline { 2 - 5 } & 1 & 0.2630 & 0.5737 & 0.1633 \\
\hline
\end{tabular}


Table 8: Multinomial logit estimation - proxy: work willingness

\begin{tabular}{|c|c|c|}
\hline & Higher contributions & Cutting pensions \\
\hline \multirow[t]{2}{*}{ Age $<25$} & 1.207 & 2.3095 \\
\hline & [0.3877] & [1.1251] \\
\hline \multirow[t]{2}{*}{ Age $>=25,<45$} & 1.4191 & $5.2716^{* * *}$ \\
\hline & [0.3713] & {$[2.0974]$} \\
\hline \multirow[t]{2}{*}{ Age $>=45,<65$} & 1.2307 & $3.1601^{* *}$ \\
\hline & [0.2884] & [1.1806] \\
\hline \multirow[t]{2}{*}{ Youth in East } & $2.0122^{* * *}$ & $2.3300^{* * *}$ \\
\hline & [0.3263] & {$[0.4814]$} \\
\hline \multirow[t]{2}{*}{ Member of union } & 0.7971 & 1.0423 \\
\hline & [0.1779] & {$[0.2897]$} \\
\hline \multirow[t]{2}{*}{ Policy interest } & $0.5507 * * *$ & $0.6431^{*}$ \\
\hline & [0.0897] & [0.1388] \\
\hline \multirow[t]{2}{*}{ Female } & 1.0089 & 0.7214 \\
\hline & [0.1559] & {$[0.1460]$} \\
\hline \multirow[t]{2}{*}{ Job insecure } & 1.6005 & 1.0317 \\
\hline & {$[0.6015]$} & {$[0.4666]$} \\
\hline \multirow[t]{2}{*}{ University } & $0.5203^{* *}$ & 0.6584 \\
\hline & {$[0.1068]$} & [0.1762] \\
\hline \multirow[t]{2}{*}{ Unemployed } & 0.9833 & 1.0862 \\
\hline & [0.3204] & {$[0.4458]$} \\
\hline \multirow[t]{2}{*}{ Not employed } & 0.6963 & $0.4624 *$ \\
\hline & [0.1637] & [0.1393] \\
\hline \multirow[t]{2}{*}{ Sick } & $1.6504 *$ & 0.9525 \\
\hline & [0.3664] & {$[0.3136]$} \\
\hline \multirow[t]{2}{*}{ Married } & 0.8817 & 0.8277 \\
\hline & {$[0.1458]$} & {$[0.1761]$} \\
\hline \multirow[t]{2}{*}{ Civil servant } & 1.4414 & 1.0966 \\
\hline & [0.5945] & [0.5529] \\
\hline \multirow[t]{2}{*}{ Entrepreneur } & $0.5043 *$ & 0.9351 \\
\hline & {$[0.1724]$} & {$[0.3620]$} \\
\hline \multirow{3}{*}{ Work willingness } & Proxy intrinsic motivatic & \\
\hline & 0.8864 & $0.4979 * *$ \\
\hline & [0.1803] & [0.1227] \\
\hline Observations & 1127 & \\
\hline Pseudo $\mathrm{R}^{2}$ & 0.0654 & \\
\hline chi2 & 143.5965 & \\
\hline $\mathrm{p}$ & 0.000 & \\
\hline
\end{tabular}

Base outcome: Increase of pension age, relative risk exposition. Standard errors in brackets.

${ }^{* * *} \mathrm{p}<0.01,{ }^{* *} \mathrm{p}<0.05,{ }^{*} \mathrm{p}<0.1$

Table 9: Predicted probabilities (work willingness)

\begin{tabular}{|c|c|c|c|c|}
\cline { 3 - 5 } \multicolumn{2}{c|}{} & \multicolumn{3}{c|}{ Reform preference } \\
\cline { 3 - 5 } \multicolumn{2}{c|}{} & $\begin{array}{c}\text { Increase } \\
\text { pension age }\end{array}$ & $\begin{array}{c}\text { Higher } \\
\text { contributions }\end{array}$ & $\begin{array}{c}\text { Cutting } \\
\text { pensions }\end{array}$ \\
\hline \multirow{3}{*}{ Work willingness } & 0 & 0.2303 & 0.5780 & 0.1917 \\
\cline { 2 - 5 } & 1 & 0.2748 & 0.6113 & 0.1139 \\
\hline
\end{tabular}




\section{Robustness}

Our findings support the empirical relevance of the preceding theoretical reasoning: Respondents with a high degree of intrinsic work motivation are more likely to opt for a postponement of the statutory retirement age. However, this result may equally reflect other links in the data structure. Although we already control for numerous important individual characteristics, missing variables could distort the regression. Thus, it cannot be excluded that intrinsic motivation is linked to a general individual inclination for reform. Furthermore, there is a straightforward alternative story which could explain our key result: It could simply be the case that workers with a physically demanding job are both less intrinsically motivated and, naturally, less optimistic that they would be capable of continuing to work at a higher age (Scheubel et al., 2009). In this case, our result would reflect the impact of job characteristics related to physical stress. In the following, we check for the reliability of our results with respect to these possible objections and also provide several regression variants to check for the general robustness of our findings.

\section{Physical job stress}

With respect to physical job stress, some of our standard control variables already have a proxy characteristic in this regard, such as gender, the education variable (university) or the profession dummies (civil servant, entrepreneur). In addition, we experimented with the following more direct control variables: (1) A dummy "hard work" which indicates that the respondent has to perform a physical straining job and (2) a dummy variable equal one if the respondent is a "blue collar" worker. These additional controls should filter out intrinsic motivation as far as it is systematically linked to job characteristics. All robustness checks were performed for both the probit (not reported) and the multinomial regressions (reported). None of the included variables seem to have any significant impact on pension reform preferences in the multinomial logit regression, while the significant impact of intrinsic motivation persists in all regressions (see Tables 10 and 11).

\section{General reform inclination}

Our theoretical reasoning for the impact of intrinsic motivation is specific to reforms related to working time. If this reasoning is indeed responsible for the data structure, we would not expect a significant impact on reform issues unrelated to working times. Significant results for 
non-work related reform issues would be a hint that intrinsic motivation is just a proxy for some other type of important individual characteristic which is not covered by our controls. To check for this possibility, we apply a placebo regression. We estimate a similar specification as in Table 2, but now for reform issues without any obvious theoretical link to intrinsic work motivation. Two different reform options are chosen which are completely unrelated to working conditions or working time: First, the approval to municipal suffrage for foreigners and, second, the compliance with the need for Islam-teaching at German schools. In none of the cases intrinsic motivation is among the significant determinants. This backs our confidence that our results on pension reform preferences are driven by the proposed causal chain and not just a general individual inclination to accept change. The results of the regressions are presented in Table 12.

\section{Further variants}

The debate on several reform proposals on the German public pension system was strongly affected by party and ideological considerations. To account for the possibility that an individual's choice for a certain reform option reflects his party preference or ideology, we control for the respondent's ideology by making use of a dummy variable indicating that he has classified himself as left-leaning. If, for instance, right-leaning individuals show a higher degree of intrinsic motivation and are also more in favor of longer working years, this would also explain our results. The inclusion does not change the substance of the results (these variants and the following ones are included in Tables 10 and 11).

Having children might also affect a person's readiness to accept certain pension reforms as it might be less desirable to impose the burden of an unsustainable system on future generations. Thus, it is reasonable to expect that individual's with children might be, for instance, less in favor of higher contributions than those without children. We include a dummy variable whether there are children at all. Including this variable, however, does not change the results.

Age is an important determinant of preferences for different reform options of the pension system as it reflects individual self-interest. Therefore, we employ numerous specification changes with respect to the measurement of the age effect (results are not reported but available upon request). First, we change the age classification by introducing closer age groups (10-year intervals). Second, we control for a non-linear relationship by employing the respondent's age as well as its square and cube. The results remain unchanged, indicating a ro- 
bust and significant age effect, i.e. younger individuals are more likely to accept pension cuts.

The significant impact of intrinsic motivation on the reform preferences persists.

Table 10: Multinominal-Logit: Robustness checks, Proxy: Like work

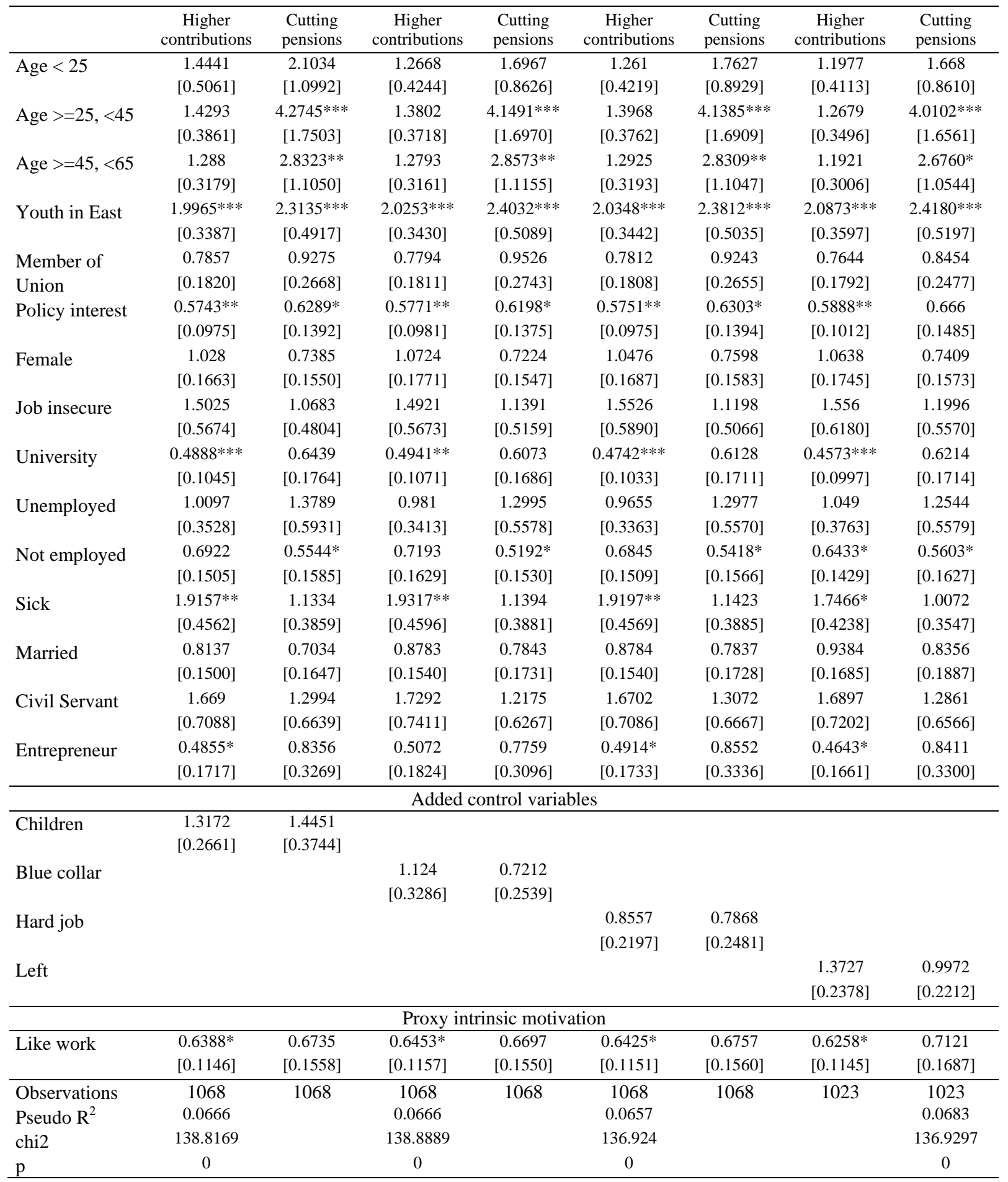

Base outcome: Increase of pension age, relative risk exposition. Standard errors in brackets.

*** $\mathrm{p}<0.01,{ }^{* *} \mathrm{p}<0.05, * \mathrm{p}<0.1$. 
Table 11: Multinominal-Logit: Robustness checks, Proxy: Work willingness

\begin{tabular}{|c|c|c|c|c|c|c|c|c|}
\hline & $\begin{array}{c}\text { Higher } \\
\text { contributions }\end{array}$ & $\begin{array}{l}\text { Cutting } \\
\text { pensions }\end{array}$ & $\begin{array}{c}\text { Higher } \\
\text { contributions }\end{array}$ & $\begin{array}{l}\text { Cutting } \\
\text { pensions }\end{array}$ & $\begin{array}{c}\text { Higher } \\
\text { contributions }\end{array}$ & $\begin{array}{l}\text { Cutting } \\
\text { pensions }\end{array}$ & $\begin{array}{c}\text { Higher } \\
\text { contributions }\end{array}$ & $\begin{array}{l}\text { Cutting } \\
\text { pensions }\end{array}$ \\
\hline Age $<25$ & $\begin{array}{c}1.3831 \\
{[0.4633]}\end{array}$ & $\begin{array}{c}2.7123^{*} \\
{[1.3634]}\end{array}$ & $\begin{array}{c}1.2257 \\
{[0.3944]}\end{array}$ & $\begin{array}{c}2.26 \\
{[1.1053]}\end{array}$ & $\begin{array}{c}1.21 \\
{[0.3888]}\end{array}$ & $\begin{array}{c}2.3284 \\
{[1.1347]}\end{array}$ & $\begin{array}{c}1.1543 \\
{[0.3821]}\end{array}$ & $\begin{array}{c}1.9876 \\
{[1.0003]}\end{array}$ \\
\hline Age $>=25,<45$ & $\begin{array}{c}1.4602 \\
{[0.3833]}\end{array}$ & $\begin{array}{c}5.4722^{* * *} \\
{[2.1844]}\end{array}$ & $\begin{array}{c}1.4055 \\
{[0.3682]}\end{array}$ & $\begin{array}{c}5.3419^{* * *} \\
{[2.1294]}\end{array}$ & $\begin{array}{c}1.4226 \\
{[0.3724]}\end{array}$ & $\begin{array}{c}5.3097 * * * \\
{[2.1144]}\end{array}$ & $\begin{array}{c}1.3304 \\
{[0.3558]}\end{array}$ & $\begin{array}{c}5.0324 * * * \\
{[2.0290]}\end{array}$ \\
\hline Age $>=45,<65$ & $\begin{array}{c}1.2284 \\
{[0.2879]}\end{array}$ & $\begin{array}{l}3.1663 * * \\
{[1.1832]}\end{array}$ & $\begin{array}{c}1.2188 \\
{[0.2860]}\end{array}$ & $\begin{array}{l}3.1974 * * \\
{[1.1952]}\end{array}$ & $\begin{array}{c}1.2329 \\
{[0.2891]}\end{array}$ & $\begin{array}{l}3.1714 * * \\
{[1.1850]}\end{array}$ & $\begin{array}{c}1.1595 \\
{[0.2780]}\end{array}$ & $\begin{array}{c}3.0108^{* *} \\
{[1.1396]}\end{array}$ \\
\hline Youth in East & $\begin{array}{c}1.9786^{* * *} \\
{[0.3217]}\end{array}$ & $\begin{array}{c}2.2765^{* * *} \\
{[0.4727]}\end{array}$ & $\begin{array}{c}2.0020^{* * *} \\
{[0.3250]}\end{array}$ & $\begin{array}{c}2.3423^{* * *} \\
{[0.4845]}\end{array}$ & $\begin{array}{c}2.0123^{* * *} \\
{[0.3263]}\end{array}$ & $\begin{array}{c}2.3309^{* * *} \\
{[0.4817]}\end{array}$ & $\begin{array}{c}2.0829 * * * \\
{[0.3444]}\end{array}$ & $\begin{array}{c}2.4142^{* * *} \\
{[0.5088]}\end{array}$ \\
\hline $\begin{array}{l}\text { Member of } \\
\text { Union }\end{array}$ & $\begin{array}{c}0.7969 \\
{[0.1782]}\end{array}$ & $\begin{array}{c}1.0396 \\
{[0.2895]}\end{array}$ & $\begin{array}{c}0.7879 \\
{[0.1766]}\end{array}$ & $\begin{array}{c}1.0668 \\
{[0.2974]}\end{array}$ & $\begin{array}{c}0.7964 \\
{[0.1778]}\end{array}$ & $\begin{array}{c}1.0381 \\
{[0.2888]}\end{array}$ & $\begin{array}{c}0.804 \\
{[0.1829]}\end{array}$ & $\begin{array}{c}0.9794 \\
{[0.2792]}\end{array}$ \\
\hline Policy interest & $\begin{array}{c}0.5481^{* * *} \\
{[0.0894]}\end{array}$ & $\begin{array}{l}0.6397^{*} \\
{[0.1383]}\end{array}$ & $\begin{array}{c}0.5545^{* * *} \\
{[0.0905]}\end{array}$ & $\begin{array}{l}0.6335^{*} \\
{[0.1372]}\end{array}$ & $\begin{array}{c}0.5506^{* * *} \\
{[0.0897]}\end{array}$ & $\begin{array}{c}0.6426^{*} \\
{[0.1388]}\end{array}$ & $\begin{array}{c}0.5611^{* * *} \\
{[0.0927]}\end{array}$ & $\begin{array}{c}0.669 \\
{[0.1462]}\end{array}$ \\
\hline Female & $\begin{array}{c}0.9804 \\
{[0.1529]}\end{array}$ & $\begin{array}{c}0.6951 \\
{[0.1424]}\end{array}$ & $\begin{array}{c}1.0391 \\
{[0.1647]}\end{array}$ & $\begin{array}{c}0.6814 \\
{[0.1419]}\end{array}$ & $\begin{array}{c}1.0072 \\
{[0.1559]}\end{array}$ & $\begin{array}{c}0.7169 \\
{[0.1453]}\end{array}$ & $\begin{array}{c}0.9966 \\
{[0.1570]}\end{array}$ & $\begin{array}{c}0.6855 \\
{[0.1418]}\end{array}$ \\
\hline Job insecure & $\begin{array}{c}1.5894 \\
{[0.5975]}\end{array}$ & $\begin{array}{c}1.0257 \\
{[0.4639]}\end{array}$ & $\begin{array}{c}1.5487 \\
{[0.5864]}\end{array}$ & $\begin{array}{c}1.0907 \\
{[0.4970]}\end{array}$ & $\begin{array}{c}1.6133 \\
{[0.6090]}\end{array}$ & $\begin{array}{c}1.0648 \\
{[0.4840]}\end{array}$ & $\begin{array}{c}1.6038 \\
{[0.6344]}\end{array}$ & $\begin{array}{c}1.1379 \\
{[0.5316]}\end{array}$ \\
\hline University & $\begin{array}{c}0.5204^{* *} \\
{[0.1069]}\end{array}$ & $\begin{array}{c}0.6599 \\
{[0.1768]}\end{array}$ & $\begin{array}{c}0.5343^{* *} \\
{[0.1112]}\end{array}$ & $\begin{array}{c}0.629 \\
{[0.1707]}\end{array}$ & $\begin{array}{c}0.5157^{* *} \\
{[0.1076]}\end{array}$ & $\begin{array}{c}0.6384 \\
{[0.1736]}\end{array}$ & $\begin{array}{c}0.4952^{* * *} \\
{[0.1036]}\end{array}$ & $\begin{array}{c}0.6474 \\
{[0.1750]}\end{array}$ \\
\hline Unemployed & $\begin{array}{c}1.0114 \\
{[0.3304]}\end{array}$ & $\begin{array}{c}1.1211 \\
{[0.4608]}\end{array}$ & $\begin{array}{c}0.9917 \\
{[0.3232]}\end{array}$ & $\begin{array}{c}1.0725 \\
{[0.4408]}\end{array}$ & $\begin{array}{c}0.9803 \\
{[0.3198]}\end{array}$ & $\begin{array}{c}1.0744 \\
{[0.4415]}\end{array}$ & $\begin{array}{c}1.0477 \\
{[0.3501]}\end{array}$ & $\begin{array}{c}1.0476 \\
{[0.4469]}\end{array}$ \\
\hline Not employed & $\begin{array}{c}0.687 \\
{[0.1617]}\end{array}$ & $\begin{array}{l}0.4570^{* *} \\
{[0.1377]}\end{array}$ & $\begin{array}{c}0.7306 \\
{[0.1780]}\end{array}$ & $\begin{array}{l}0.4305^{* *} \\
{[0.1336]}\end{array}$ & $\begin{array}{c}0.6912 \\
{[0.1640]}\end{array}$ & $\begin{array}{l}0.4496^{* *} \\
{[0.1369]}\end{array}$ & $\begin{array}{l}0.6084 * \\
{[0.1472]}\end{array}$ & $\begin{array}{c}0.4449 * * \\
{[0.1378]}\end{array}$ \\
\hline Sick & $\begin{array}{l}1.6481^{*} \\
{[0.3662]}\end{array}$ & $\begin{array}{c}0.9495 \\
{[0.3128]}\end{array}$ & $\begin{array}{l}1.6586^{*} \\
{[0.3683]}\end{array}$ & $\begin{array}{c}0.944 \\
{[0.3115]}\end{array}$ & $\begin{array}{l}1.6487^{*} \\
{[0.3661]}\end{array}$ & $\begin{array}{c}0.9517 \\
{[0.3133]}\end{array}$ & $\begin{array}{c}1.5015 \\
{[0.3402]}\end{array}$ & $\begin{array}{c}0.8378 \\
{[0.2865]}\end{array}$ \\
\hline Married & $\begin{array}{c}0.8218 \\
{[0.1422]}\end{array}$ & $\begin{array}{c}0.7571 \\
{[0.1704]}\end{array}$ & $\begin{array}{c}0.883 \\
{[0.1461]}\end{array}$ & $\begin{array}{c}0.8313 \\
{[0.1772]}\end{array}$ & $\begin{array}{c}0.8828 \\
{[0.1460]}\end{array}$ & $\begin{array}{c}0.829 \\
{[0.1765]}\end{array}$ & $\begin{array}{c}0.9227 \\
{[0.1572]}\end{array}$ & $\begin{array}{c}0.8472 \\
{[0.1855]}\end{array}$ \\
\hline Civil Servant & $\begin{array}{c}1.4364 \\
{[0.5928]}\end{array}$ & $\begin{array}{c}1.0847 \\
{[0.5482]}\end{array}$ & $\begin{array}{c}1.5141 \\
{[0.6304]}\end{array}$ & $\begin{array}{c}1.0179 \\
{[0.5186]}\end{array}$ & $\begin{array}{c}1.4396 \\
{[0.5935]}\end{array}$ & $\begin{array}{c}1.09 \\
{[0.5501]}\end{array}$ & $\begin{array}{c}1.4177 \\
{[0.5878]}\end{array}$ & $\begin{array}{c}1.0632 \\
{[0.5378]}\end{array}$ \\
\hline Entrepreneur & $\begin{array}{l}0.4992^{*} \\
{[0.1712]} \\
\end{array}$ & $\begin{array}{c}0.9226 \\
{[0.3583]} \\
\end{array}$ & $\begin{array}{c}0.5333 \\
{[0.1859]} \\
\end{array}$ & $\begin{array}{c}0.8658 \\
{[0.3423]} \\
\end{array}$ & $\begin{array}{l}0.5059 * \\
{[0.1731]} \\
\end{array}$ & $\begin{array}{c}0.9501 \\
{[0.3684]} \\
\end{array}$ & $\begin{array}{l}0.4842^{*} \\
{[0.1679]} \\
\end{array}$ & $\begin{array}{c}0.9089 \\
{[0.3541]} \\
\end{array}$ \\
\hline \multicolumn{9}{|c|}{ Added control variables } \\
\hline Children & $\begin{array}{c}1.3196 \\
{[0.2544]}\end{array}$ & $\begin{array}{c}1.3887 \\
{[0.3506]}\end{array}$ & & & & & & \\
\hline Blue collar & & & $\begin{array}{c}1.2279 \\
{[0.3552]}\end{array}$ & $\begin{array}{c}0.7406 \\
{[0.2604]}\end{array}$ & & & & \\
\hline Hard job & & & & & $\begin{array}{c}0.9381 \\
{[0.2384]}\end{array}$ & $\begin{array}{c}0.8187 \\
{[0.2584]}\end{array}$ & & \\
\hline Left & & & & & & & $\begin{array}{c}1.3198 \\
{[0.2189]} \\
\end{array}$ & $\begin{array}{c}0.9993 \\
{[0.2160]} \\
\end{array}$ \\
\hline \multicolumn{9}{|c|}{ Proxy intrinsic motivation } \\
\hline $\begin{array}{l}\text { Work } \\
\text { willingness }\end{array}$ & $\begin{array}{c}0.8834 \\
{[0.1799]} \\
\end{array}$ & $\begin{array}{l}0.4959 * * \\
{[0.1224]} \\
\end{array}$ & $\begin{array}{c}0.8904 \\
{[0.1812]} \\
\end{array}$ & $\begin{array}{l}0.4934^{* *} \\
{[0.1219]} \\
\end{array}$ & $\begin{array}{c}0.8881 \\
{[0.1805]} \\
\end{array}$ & $\begin{array}{l}0.4968^{* *} \\
{[0.1225]} \\
\end{array}$ & $\begin{array}{c}0.8131 \\
{[0.1704]} \\
\end{array}$ & $\begin{array}{l}0.5016^{* *} \\
{[0.1268]} \\
\end{array}$ \\
\hline $\begin{array}{l}\text { Observations } \\
\text { Pseudo } \mathrm{R}^{2}\end{array}$ & $\begin{array}{c}1127 \\
0.0665\end{array}$ & 1127 & $\begin{array}{c}1127 \\
0.0669\end{array}$ & 1127 & $\begin{array}{c}1127 \\
0.0656\end{array}$ & 1127 & $\begin{array}{c}1078 \\
0.0681\end{array}$ & 1078 \\
\hline chi2 & 146.055 & & 147.0021 & & 144.0257 & & 143.6289 & \\
\hline $\mathrm{p}$ & 0 & & 0 & & 0 & & 0 & \\
\hline
\end{tabular}

Base outcome: Increase of pension age, relative risk exposition. Standard errors in brackets.

$* * * \mathrm{p}<0.01, * * \mathrm{p}<0.05, * \mathrm{p}<0.1$. 
Table 12: Probit estimation: Placebo regression

\begin{tabular}{|c|c|c|c|c|}
\hline & $\begin{array}{l}\text { Municipal } \\
\text { Suffrage }\end{array}$ & $\begin{array}{l}\text { Municipal } \\
\text { Suffrage }\end{array}$ & $\begin{array}{c}\text { Islam } \\
\text { Teaching }\end{array}$ & $\begin{array}{c}\text { Islam } \\
\text { Teaching }\end{array}$ \\
\hline \multirow[t]{2}{*}{ Age $<25$} & $0.116^{*}$ & $0.185^{* * *}$ & $0.181 * * *$ & $0.117 * * *$ \\
\hline & {$[0.0610]$} & [0.0406] & [0.0653] & [0.0427] \\
\hline \multirow{2}{*}{ Age $>=25,<45$} & 0.0773 & $0.119 * * *$ & $0.122 * * *$ & $0.107 * * *$ \\
\hline & {$[0.0480]$} & [0.0324] & [0.0457] & [0.0307] \\
\hline \multirow[t]{2}{*}{ Age $>=45,<65$} & 0.0488 & $0.0825^{* * *}$ & $0.108^{* *}$ & $0.0979 * * *$ \\
\hline & {$[0.0448]$} & {$[0.0300]$} & [0.0424] & [0.0281] \\
\hline \multirow[t]{2}{*}{ Youth in East } & 0.0364 & $0.0467 * *$ & $-0.280 * * *$ & $-0.266 * * *$ \\
\hline & [0.0284] & [0.0194] & [0.0219] & [0.0154] \\
\hline \multirow[t]{2}{*}{ Member of union } & 0.0580 & $0.0677 * *$ & 0.0270 & 0.00840 \\
\hline & [0.0413] & [0.0291] & [0.0372] & {$[0.0264]$} \\
\hline \multirow[t]{2}{*}{ Policy interest } & $0.0705^{* *}$ & $0.0513^{* *}$ & $0.0823^{* * *}$ & $0.0823 * * *$ \\
\hline & [0.0313] & [0.0213] & {$[0.0290]$} & [0.0200] \\
\hline \multirow[t]{2}{*}{ Female } & 0.0143 & 0.00257 & $0.0784^{* * *}$ & $0.0717 * * *$ \\
\hline & [0.0283] & [0.0193] & {$[0.0252]$} & [0.0176] \\
\hline \multirow[t]{2}{*}{ Job insecure } & -0.0698 & -0.0506 & 0.0554 & 0.0223 \\
\hline & {$[0.0526]$} & {$[0.0371]$} & {$[0.0531]$} & {$[0.0368]$} \\
\hline \multirow[t]{2}{*}{ University } & 0.0395 & $0.0980 * * *$ & $0.0912 * *$ & $0.0857 * * *$ \\
\hline & [0.0410] & [0.0273] & [0.0402] & {$[0.0266]$} \\
\hline \multirow[t]{2}{*}{ Unemployed } & $-0.0911^{*}$ & $-0.0809 * *$ & $-0.0867 *$ & $-0.0622 *$ \\
\hline & [0.0553] & {$[0.0380]$} & [0.0449] & [0.0333] \\
\hline \multirow[t]{2}{*}{ Not employed } & 0.0568 & $0.0474^{*}$ & $0.0854 * *$ & $0.0883 * * *$ \\
\hline & [0.0382] & {$[0.0271]$} & [0.0332] & [0.0241] \\
\hline \multirow[t]{2}{*}{ Sick } & $-0.114 * * *$ & $-0.0474 *$ & -0.0264 & $-0.0406^{*}$ \\
\hline & [0.0382] & {$[0.0270]$} & [0.0353] & {$[0.0241]$} \\
\hline \multirow[t]{2}{*}{ Married } & 0.00881 & 0.0126 & $0.0513^{*}$ & $0.0380 * *$ \\
\hline & [0.0301] & {$[0.0206]$} & [0.0267] & {$[0.0186]$} \\
\hline \multirow[t]{2}{*}{ Civil servant } & 0.105 & 0.0547 & 0.0510 & 0.0738 \\
\hline & {$[0.0776]$} & {$[0.0547]$} & {$[0.0701]$} & {$[0.0518]$} \\
\hline \multirow[t]{2}{*}{ Entrepreneur } & 0.0893 & $0.101^{* *}$ & 0.0202 & 0.0243 \\
\hline & {$[0.0621]$} & {$[0.0424]$} & {$[0.0578]$} & [0.0399] \\
\hline \multicolumn{5}{|c|}{ Proxies intrinsic motivation } \\
\hline \multirow[t]{2}{*}{ Like work } & 0.00141 & & 0.0377 & \\
\hline & [0.0303] & & [0.0261] & \\
\hline \multirow[t]{2}{*}{ Work willingness } & & -0.00463 & & -0.0114 \\
\hline & & [0.0262] & & {$[0.0237]$} \\
\hline Observations & 1,377 & 2,909 & 1,360 & 2,885 \\
\hline Pseudo R ${ }^{2}$ & 0.0182 & 0.0186 & 0.126 & 0.104 \\
\hline
\end{tabular}

Marginal effects, standard errors in brackets

$* * * \mathrm{p}<0.01, * * \mathrm{p}<0.05, * \mathrm{p}<0.1$ 


\section{Conclusion}

Our findings suggest that intrinsic work motivation is indeed a relevant driver of work-related reform processes - at least with respect to the formation of pension reform preferences. The empirical results confirm the predictions of our theoretical reasoning, which makes a clear case for the existence of such a link. Our intrinsic motivation proxies prove to be robustly significant in a series of econometric tests, in which we pay careful attention to an individual's physical job stress and apply numerous modifications to the included control variables. For a multitude of specifications, respondents who experience utility from their work beyond the money they earn are more willing to embark on reforms leading to a higher pension age.

This key result has implications both for the intrinsic motivation literature and our understanding of reform processes. So far, intrinsic motivation has been recognized to be important for the efficiency of firms and organizations. Our findings point beyond that insight towards the formation of policy preferences and the adaptability of modern welfare states and societies. A lack of non-monetary incentives will contribute to the blockade of reforms which require more work effort. Hence, a society for which work is perceived as a nuisance will have much larger problems to adjust to the necessities of demographic change compared to a society with high work ethics.

We know from the intrinsic motivation literature that this type of motivation is not purely exogenous. For example, adequate payment systems are known to foster job satisfaction and performance (Ockenfels et al., 2010). With our results, this type of findings can be interpreted in a new light. Indirectly, the same measures would also help to transform reform preferences and the available policy space for reform decisions. Policies that target at increasing the acceptance for longer working years or working hours should, therefore, invest high efforts in increasing job satisfaction. In this sense, governments should be aware that the acceptance of work related reforms is partially determined at the workplace. 


\section{References}

Alesina, Alberto and Nicola Fuchs-Schündeln (2007), Good by Lenin (or not?): The effect of Communism on People's Prefrences, American Economic Review 97, 1507-1528.

Bénabou, Roland and Jean Tirole (2003), Intrinsic and Extrinsic Motivation, Review of Economic Studies 70, 489-520.

Bénabou, Roland and Jean Tirole (2006), Incentives and Prosocial Behavior, American Economic Review 96 (5), 1652-1678.

Blekesaune, Morten and Per Erik Solem (2005), Working Conditions and Early Retirement, Research on Aging 27 (1), 3-30.

Boeri, Tito, Axel Börsch-Supan and Guido Tabellini (2001), Would you like to shrink the European welfare state? A survey of European citizens, Economic Policy 16 (32), 950.

Boeri, Tito, Axel Börsch-Supan and Guido Tabellini (2002), Pension Reforms and the Opinions of European Citizens, American Economic Review 92 (2), 396-401.

Boeri, Tito and Guido Tabellini (2010), Does information increase political support for pension reform?, Public Choice, 1-36.

Börsch-Supan, Axel, Simone Kohnz and Reinhold Schnabel (2007), Budget effects of pension reform in Germany, in: J. Gruber and D. Wise (Hrsg.), Social security programs and retirement around the world: Fiscal implications. University of Chicago Press, Chicago.

Börsch-Supan, Axel, Reinhold Schnabel, Simone Kohnz and Giovanni Mastrobuoni (2004), Micro-modelling of retirement decisions in Germany, in: J. Gruber and D. Wise (Hrsg.), Social security programs and retirement around the world: Fiscal implications. University of Chicago Press, Chicago.

Cornelißen, Thomas (2006), Job characteristics as determinants of job satisfaction and labour mobility, Discussion Paper No. 334, Institute of Quantitative Economic Research, University of Hannover, Germany, 25.

Deci, Edward L. (1971), Effects of externally mediated rewards on intrinsic motivation, Journal of Personality and Social Psychology 18 (1), 105-115.

Diaz-Serrano, Luis and Jose A. Cabral Vieira (2005), Low-pay higher pay and job satisfaction within the European Union empirical evidence from fourteen countries, IZA Discussion Paper No. 1558, 26.

Filer, Randall and Marjorie Honig (2005), Endogenous Pensions and Retirement Behavior, CESifo Working Paper No. 1547.

Frey, Bruno (1997a), Markt und Motivation: Wie ökonomische Arbeitsanreize die (Arbeits-) Moral verdrängen. Vahlen, München.

Frey, Bruno (1997b), On the relationship between intrinsic and extrinsic work motivation, International Journal of Industrial Organization 15, 427-439.

Frey, Bruno (2008), Motivation crowding theory - a new approach to behaviour, in: Productivity Commission (Hrsg.), Behavioural Economics and Public Policy. Roundtable Proceedings, Productivity Commission, Canberra, 37-54.

Frey, Bruno and Reto Jegen (2001), Motivation Crowding Theory: A Survey of Empirical Evidence, Journal of Economic Surveys 15 (5), 589-611.

Gruber, Jonathan and David A. Wise (2004), Social security programs and retirement around the world: Micro-estimation. University of Chicago Press, Chicago.

Gruber, Jonathan and David A. Wise (2007), Social security programs and retirement around the world: Fiscal implications. University of Chicago Press, Chicago.

Lazear, Edward P. (1979), Why is there mandatory retirement?, Journal of Political Economy 87, 1261-1284. 
Lynch, Julia and Mikko Myrskylä (2009), Always the Third Rail? Pension Income and Policy Preferences in European Democracies, Comparative Political Studies 42 (8), 1068 1097.

Meltzer, Allan H. and Scott F. Richard (1981), A Rational Theory of the Size of Government, Journal of Political Economy 89 (5), 914-927.

Mortensen, Dale T. (1978), Specific Capital and Labor Turnover, The Bell Journal of Economics 9 (2), 572-586.

Ockenfels, Axel, Dirk Sliwka and Peter Werner (2010), Bonus Payments and Reference Point Violations, IZA Discussion Paper No. 4795, 31.

Osterloh, Margit and Bruno Frey (2000), Motivation, Knowledge Transfer, and Organizational Forms, Organization Science 11 (5), 538-550.

Osterloh, Margit, Jetta Frost and Bruno Frey (2002), The Dynamics of Motivation in New Organizational Forms, International Journal of the Economics of Business 9 (1), 6177.

Scheubel, Beatrice, Daniel Schunk and Joachim Winter (2009), Don’t Raise the Retirement Age! An Experiment on Opposition to Pension Reforms and East-West Differences in Germany, CESifo Working Paper No. 2752.

Schneider, Ondrej (2009), Reforming Pensions in Europe: Economic Fundamentals and Political Factors, CESifo Working Paper No. 2572.

Sinn, Hans-Werner and Silke Übelmesser (2002), Pensions and the path to gerontocracy in Germany, European Journal of Political Economy 19, 153-158.

Terwey, Michael, Arno Bens, Horst Baumann and Stefan Baltzer (2007), Datenhandbuch ALLBUS 2006. ZA - Nr. 4500. GESIS, Köln und Mannheim. 
Appendix: Variable definitions

\begin{tabular}{|c|c|c|c|c|}
\hline Variable & Unit & Explanation & Categories & $\begin{array}{l}\text { ALLBUS } \\
\text { code* }\end{array}$ \\
\hline \multicolumn{5}{|c|}{ Reform Option Indicator } \\
\hline $\begin{array}{l}\text { Increase of } \\
\text { pension age } \\
\text { preference }\end{array}$ & Dummy & $\begin{array}{l}\text { Increase of pension age to solve the } \\
\text { problems of the public pension } \\
\text { system. }\end{array}$ & $\begin{array}{l}1 \text { if the respondent approves, } 0 \\
\text { otherwise. }\end{array}$ & v605 \\
\hline $\begin{array}{l}\text { Higher contri- } \\
\text { bution prefer- } \\
\text { ence }\end{array}$ & Dummy & $\begin{array}{l}\text { Higher contributions to solve the } \\
\text { problems of the public pension } \\
\text { system. }\end{array}$ & $\begin{array}{l}1 \text { if the respondent approves, } 0 \\
\text { otherwise. }\end{array}$ & v605 \\
\hline $\begin{array}{l}\text { Cutting pension } \\
\text { preference }\end{array}$ & Dummy & $\begin{array}{l}\text { Lower pension payment from pub- } \\
\text { lic pension system as solution of the } \\
\text { current and facing problems. }\end{array}$ & $\begin{array}{l}1 \text { if the respondent approves, } 0 \\
\text { otherwise. }\end{array}$ & v605 \\
\hline \multicolumn{5}{|l|}{ Controls } \\
\hline Age $<25$ & Dummy & Younger than 25 years. & $\begin{array}{l}1 \text { for respondents aged } 18 \text { to } 24,0 \\
\text { otherwise. }\end{array}$ & v27 \\
\hline Age $>=25,<45$ & Dummy & Between 25 and 45 years old. & $\begin{array}{l}1 \text { for respondents aged } 25 \text { to } 45,0 \\
\text { otherwise. }\end{array}$ & v27 \\
\hline Age $>=45,<65$ & Dummy & Between 45 and 65 years old. & $\begin{array}{l}1 \text { for respondents aged } 45 \text { to } 65,0 \\
\text { otherwise. }\end{array}$ & v27 \\
\hline Job insecure & Dummy & Job insecurity of the respondent. & $\begin{array}{l}1 \text { if the respondent is employed } \\
\text { and is afraid of becoming unem- } \\
\text { ployed, } 0 \text { otherwise. }\end{array}$ & v188, v210 \\
\hline Unemployed & Dummy & $\begin{array}{l}\text { Employment status of the respond- } \\
\text { ent. }\end{array}$ & $\begin{array}{l}1 \text { if the respondent is currently } \\
\text { unemployed, } 0 \text { otherwise. }\end{array}$ & v188, v217 \\
\hline Not employed & Dummy & $\begin{array}{l}\text { Employment status of the respond- } \\
\text { ent. }\end{array}$ & $\begin{array}{l}1 \text { if the respondent is currently not } \\
\text { employed (e.g. including materni- } \\
\text { ty, unemployment, disability, } \\
\text { pension), } 0 \text { otherwise. }\end{array}$ & v188 \\
\hline Civil servant & Dummy & $\begin{array}{l}\text { Occupational position of the re- } \\
\text { spondent: civil servant. }\end{array}$ & $\begin{array}{l}1 \text { if the respondent is a civil serv- } \\
\text { ant, } 0 \text { otherwise. }\end{array}$ & v188, v189 \\
\hline Entrepreneur & Dummy & $\begin{array}{l}\text { Occupational position of the re- } \\
\text { spondent: entrepreneur or self- } \\
\text { employed professional. }\end{array}$ & $\begin{array}{l}1 \text { if the respondent is self- } \\
\text { employed, } 0 \text { otherwise. }\end{array}$ & v188, v189 \\
\hline Sick & Dummy & Health condition of the respondent. & $\begin{array}{l}1 \text { if the respondent feels not (very) } \\
\text { healthy, } 0 \text { otherwise. }\end{array}$ & v241 \\
\hline University & Dummy & Respondent’s educational level. & $\begin{array}{l}1 \text { if the respondent has a universi- } \\
\text { ty (for applied science) degree, } 0 \\
\text { otherwise. }\end{array}$ & v184, v185 \\
\hline Policy interest & Dummy & $\begin{array}{l}\text { Respondent claims to be interested } \\
\text { in politics. }\end{array}$ & $\begin{array}{l}1 \text { if the respondent approves, } 0 \\
\text { otherwise. }\end{array}$ & v139 \\
\hline $\begin{array}{l}\text { Member of } \\
\text { union }\end{array}$ & Dummy & Membership in a trade union. & $\begin{array}{l}1 \text { if the respondent is a member of } \\
\text { a trade union, } 0 \text { otherwise. }\end{array}$ & v503 \\
\hline Youth in East & Dummy & $\begin{array}{l}\text { State in which the respondent spent } \\
\text { his youth. }\end{array}$ & $\begin{array}{l}1 \text { if the respondent spent his youth } \\
\text { in the former GDR, } 0 \text { otherwise. }\end{array}$ & v37 \\
\hline Female & Dummy & Sex of the respondent. & $\begin{array}{l}1 \text { if the respondent is female, } 0 \\
\text { otherwise. }\end{array}$ & v174 \\
\hline Married & Dummy & Marital status of the respondent. & $\begin{array}{l}1 \text { if the respondent is married, } 0 \\
\text { otherwise. }\end{array}$ & v242 \\
\hline
\end{tabular}




\begin{tabular}{|c|c|c|c|c|}
\hline \multicolumn{5}{|c|}{ Intrinsic Work Motivation } \\
\hline Like work & Dummy & $\begin{array}{l}\text { Willingness to work, even if there is } \\
\text { no need for money. }\end{array}$ & $\begin{array}{l}1 \text { if the respondent strongly ap- } \\
\text { proves, } 0 \text { otherwise. }\end{array}$ & v536 \\
\hline $\begin{array}{l}\text { Work } \\
\text { willingness }\end{array}$ & Dummy & $\begin{array}{l}\text { Willingness to work harder to } \\
\text { support the firm or organization. }\end{array}$ & $\begin{array}{l}1 \text { if the respondent is employed } \\
\text { and is willing to work harder, } \\
0 \text { otherwise. }\end{array}$ & v578, v188 \\
\hline \multicolumn{5}{|c|}{ Placebo Regression } \\
\hline $\begin{array}{l}\text { Municipal } \\
\text { Suffrage }\end{array}$ & Dummy & $\begin{array}{l}\text { Reform proposal: Municipal suf- } \\
\text { frage for foreigner. }\end{array}$ & $\begin{array}{l}1 \text { if the respondent approves, } 0 \\
\text { otherwise. }\end{array}$ & v104 \\
\hline Islam Teaching & Dummy & $\begin{array}{l}\text { Reform proposal: Islam teaching at } \\
\text { state schools in Germany. }\end{array}$ & $\begin{array}{l}1 \text { if the respondent approves, } 0 \\
\text { otherwise. }\end{array}$ & v105 \\
\hline \multicolumn{5}{|c|}{ Robustness Checks } \\
\hline Children & Dummy & $\begin{array}{l}\text { Children living in the respondent's } \\
\text { household. }\end{array}$ & $\begin{array}{l}1 \text { if the respondent has at least one } \\
\text { child, } 0 \text { otherwise. }\end{array}$ & v443 \\
\hline Blue collar & Dummy & Respondent's job position. & $\begin{array}{l}1 \text { if the respondent is employed } \\
\text { and is a blue collar worker, } \\
0 \text { if not. }\end{array}$ & v188, v189 \\
\hline Hard Job & Dummy & $\begin{array}{l}\text { Respondent has a physically de- } \\
\text { manding job. }\end{array}$ & $\begin{array}{l}1 \text { if the respondent is employed } \\
\text { and has to perform a physically } \\
\text { demanding job, } 0 \text { otherwise. }\end{array}$ & v188, v564 \\
\hline Left & Dummy & $\begin{array}{l}\text { Self-assessment of respondent's } \\
\text { ideology. }\end{array}$ & $\begin{array}{l}1 \text { if the respondent classifies } \\
\text { herself as left, } 0 \text { otherwise. }\end{array}$ & v145 \\
\hline
\end{tabular}

* The codes referring to the questions are taken from the German Codebook (Terwey et al., 2007). 